\title{
The Application Research on Waste Clay Brick in the Cement Concrete
}

\author{
Cheng-qin Chen, Yi-lin Zhang, Wei Zhang and Yu-chun Zhang \\ Northwest University for Nationalities Lanzhou 730124, China \\ Key Laboratory of New Laboratory of New Building Materials and Building Energy-saving of Gansu Province Lanzhou 730030, China
}

\begin{abstract}
The construction waste has been produced more and more with the rapid development of urbanization and industrialization in China in recent years. The waste clay brick of construction waste named recycled coarse aggregate was mixed with cement concrete mainly by making laboratory experimental study. The clay brick as recycled coarse aggregate was mixed into the concrete at $0 \%, 20 \%, 25 \%, 30 \%, 35 \%, 40 \%, 50 \%, 60 \%, 70 \%, 80 \%$, $100 \%$ and fixed water-cement ratio according to references at home and abroad, which made the $\mathrm{C} 30$ standard test blocks, and strictly controlled the variable of the coarse aggregate replacement rate; the slump and 7-day compressive strength were measured, and their performance was compared with that of the standard C30 concrete specimen; the optimum range of incorporation of recycled aggregate would be put forward according to their performance. This result would have a certain significance in waste bricks.
\end{abstract}

\section{Introduction}

The demand for construction resources has been rapidly growing with the rapid development of urbanization and industrialization in China in recent years, along with more and more construction waste generated. The current construction waste production has reached about 800 million and 0.6 tons per capita; the amount of waste generated in the construction of the future are predicted that the future construction waste production will reach 10 million tons in 10 years [1]-[5]. The number of construction waste generated in urban construction has accounted for $30 \%-40 \%$ of the total municipal solid waste according to the survey; the vast part of the construction waste is being transported directly into the wild pile or landfill, which will occupy a lot of land, and even the occupation of arable land and farmland. Construction waste will be nowhere in a certain time if they are dealt with in this way a long-term [1]-[5]. While construction debris during transportation will produce dust, gray sand flying and other issues, bring about a lot of pollution to the environment, and lead to people's lives inconvenience. They will also have a small fortune in fees during transportation. It is said that these waste is such as resources that were just put in the wrong place. A lot of research institutions have been conducting research in foreign countries, and made great achievements. Construction waste utilization it is not very common in the domestic, so people can fully draw on advanced foreign technology and processing methods to use construction waste combined with China's actual situation. The foregoing analysis shows that the construction waste recycled has become an urgent problem.
The waste clay brick would be used to replace part of the coarse aggregate in the concrete as recycled coarse aggregate. The technical indicators would be made by crushing test, and to mix design a concrete thickness C30 according to the aggregate value; the recycled coarse aggregate were incorporated into the concrete at $0 \%, 20 \%$, $25 \%, 30 \%, 35 \%, 40 \%, 50 \%, 60 \%, 70 \%, 80 \%, 100 \%$ by a fixed water-cement ratio method, formulating a standard block to measure the compressive strength; the best incorporation of recycled aggregate value range would be obtained.

\section{Raw materials and technical indicators}

The raw materials contain natural pebbles in Yuzhong County, river sand clay brick construction waste, and naphthalene superplasticizer, P.O 42.5, etc. Their technical indicators were shown in Table 1.

\subsection{The main formulas [6]}

a. The bulk density of natural coarse aggregate and fine aggregate:

$$
\rho_{0}{ }^{\prime}=\left(m_{2}-m_{1}\right) / v_{0}{ }^{\prime} * 1000
$$

where: $m_{1}$ - Capacity cartridge mass, $\mathrm{kg} ; m_{2}$ - Capacity cartridge and gravel mass, $\mathrm{kg}$

$$
v_{0} \text { '-Capacity cartridge volume, L }
$$

b. The crushing index of natural coarse aggregate:

$$
\text { Crushing index: }=\left(G_{0}-G_{1}\right) / G_{0} \times 100 \%
$$

where: $G_{0}$-Sample mass, $\mathrm{kg} ; G_{l}$-Sieve allowance, $\mathrm{kg}$ 
c. The fineness modulus of fine aggregate:

$$
M x=\left[\left(A_{2}+A_{3}+A_{4}+A_{5}+A_{6}\right)-5 A_{1}\right] /\left(100-A_{1}\right)
$$

\subsection{General technical indexes}

The cementitious material is P.O 42.5, and its technical indexes are seen in Table 1 . The naphthalene superplasticizer as water reducing agent was used in this experiment, which the water reduction rate of $20 \%$ was measured; the appearance took on yellow powder; the solid content was greater than $92 \%$; $\mathrm{PH}$ value $(5 \%$ aqueous solution)was 7-9; sodium content was $16-19 \%$; cement paste fluidity was not less than $200 \mathrm{~mm}$; the concrete strength increases by $15-40 \%$ at early and night strength for the significant concrete to enhance the effect; it fully improves and enhances the physical and mechanical properties of concrete, and save $10-20 \%$ of cement maintaining the strength of the same; it has no corrosion of steel effect.

The recycled aggregate [7], [8] is mainly clay brick used in building demolition wall materials. The collected clay bricks were crushed with jaw crusher; then they were used the standard sieving to sieve and done an adjustments in accordance with the norms [9]. The aggregate Technical indicators were shown in Table 2.

Table 1. The Technical indicators of P.O42.5.

\begin{tabular}{|c|c|c|c|c|c|}
\hline Num. & \multicolumn{2}{|c|}{ Test items } & $\begin{array}{l}\text { Technical } \\
\text { indicators }\end{array}$ & $\begin{array}{l}\text { The } \\
\text { results }\end{array}$ & $\begin{array}{l}\text { Result } \\
\text { verdict }\end{array}$ \\
\hline 1 & \multicolumn{2}{|c|}{ Density $\left(\mathrm{kg} / \mathrm{m}^{3}\right)$} & / & 3161 & 1 \\
\hline 2 & \multicolumn{2}{|c|}{$\begin{array}{l}\text { The specific surface } \\
\text { area }\left(\mathrm{m}^{2} / \mathrm{kg}\right)\end{array}$} & $\nless 300$ & 342 & qualified \\
\hline 3 & \multicolumn{2}{|c|}{$\begin{array}{l}\text { Standard consistency } \\
\text { water }(\%)\end{array}$} & - & 27.41 & / \\
\hline 4 & \multirow[t]{2}{*}{$\begin{array}{l}\text { Setting time } \\
(\min )\end{array}$} & \begin{tabular}{|l|} 
Initial \\
setting
\end{tabular} & $\nless 45$ & 252 & qualified \\
\hline 5 & & $\begin{array}{l}\text { Final } \\
\text { setting }\end{array}$ & $\ngtr 600$ & 400 & qualified \\
\hline 6 & \multicolumn{2}{|c|}{ Stability } & $\ngtr 5.0$ & 0.6 & qualified \\
\hline \multirow[t]{4}{*}{7} & \multirow{2}{*}{$\begin{array}{l}\text { Flexural } \\
\text { strength } \\
(\mathrm{MPa}) \\
\end{array}$} & $3 d$ & $\nless 3.5$ & 4.6 & qualified \\
\hline & & $28 \mathrm{~d}$ & $\nless 6.5$ & 7.5 & qualified \\
\hline & \multirow{2}{*}{$\begin{array}{l}\text { Compressive } \\
\text { strength } \\
\text { (MPa) }\end{array}$} & $3 \mathrm{~d}$ & $\nless 17.0$ & 25.8 & qualified \\
\hline & & $28 \mathrm{~d}$ & $\nless 42.5$ & 48.3 & qualified \\
\hline
\end{tabular}

Table 2. The aggregate technical indicators.

\begin{tabular}{|c|c|c|c|c|}
\hline $\begin{array}{c}\text { Aggregate } \\
\text { Type }\end{array}$ & $\begin{array}{c}\text { Particle } \\
\mathbf{s i z e} \\
\mathbf{( m m )}\end{array}$ & $\begin{array}{c}\text { Bulk } \\
\mathbf{d e n s i t y} \\
\mathbf{( k g / \mathbf { m } ^ { 3 }}\end{array}$ & $\begin{array}{c}\text { Crushin } \\
\mathbf{g} \text { index } \\
\mathbf{( \% )}\end{array}$ & \multirow{2}{*}{$\mathbf{M}_{\boldsymbol{x}}$} \\
\cline { 1 - 3 } $\begin{array}{c}\text { Coarse } \\
\text { aggregate }\end{array}$ & $5-31.5$ & 1663 & 7.95 & \multirow{2}{*}{--} \\
\cline { 1 - 3 } $\begin{array}{c}\text { recycled } \\
\text { aggregate }\end{array}$ & $5-31.5$ & 952.43 & -- & \\
\cline { 1 - 3 } $\begin{array}{c}\text { Fine } \\
\text { aggregate }\end{array}$ & $0-5$ & 1258 & -- & 3.67 \\
\hline
\end{tabular}

Table 2 showed: the stone is belong to I Class stones by the crushed index value. The sand is I sand area, names the coarse sand.

\section{Mix design and production of standard specimens}

The trial mixture - $\mathrm{C} 30$ concrete was used to make the mixture design, which the mix proportion was that: cement: $328.89 \mathrm{~kg}$, sand: $673.09 \mathrm{~kg}$, stones: $1250.02 \mathrm{~kg}$, water: $148 \mathrm{~kg}$, water reducer: $3.29 \mathrm{~kg}$. The recycled coarse aggregate was prepared to make cement concrete block; the variable of the coarse aggregate replacement rate was strictly controlled th the test process; recycled coarse aggregate was substituted to make six test groups at respectively $0 \%, 20 \%, 25 \%, 30 \%, 35 \%, 40 \%, 50 \%, 60 \%$, $70 \%, 80 \%, 100 \%$. The standard test pieces were made with $150 \mathrm{~mm} \times 150 \mathrm{~mm} \times 150 \mathrm{~mm}$, and measured for slump and 7-day compressive strength.

The conservation and test methods for the production of test pieces were mixed strictly in accordance with the standard [10], and the specimens were allowed to stand to form removal after $24 \mathrm{~h}$ pouring in the laboratory; the blocks were made with conservation trials to $7 \mathrm{~d}$ after curing under standard conditions.

Since the water absorption of recycled aggregate clay brick was large to bring a lot of trouble, the recycled aggregate was selected to be soaked firstly before making aggregate mixing through experimental analysis; the aggregate fully absorb the moisture, and then dried the aggregate surface, which solves the problem.

\section{Analysis of experimental data}

The mix proportion used was shown in Table 3.

Coarse aggregate replacement rate: the recycled aggregate volume is equal to the volume of natural aggregate; the bulk density of natural coarse aggregate and recycled coarse aggregate is not the same; the equal volume substitution was taken in the test in order to make the data more reliable.

The concrete slump was measured during the test and the compression testing data in the universal testing machine compression were obtained in Table 4. The incorporation of recycled aggregate concrete had impact on the strength shown in Fig. 1.

Fig. 1 showed: the overall compressive strength firstly trends to increase. Then decrease with the increase in the aggregate amount of renewable incorporated under other factors invariable; the test piece reached to the maximum compressive strength when the amount reaches $25 \%$. Also the recycled aggregate amount was among $20 \%$ to $35 \%$, the strength of concrete is greatly improved.

In conclusion, the compressive strength added to the recycled aggregate is higher than that of made of natural aggregate; there are two reasons for primary analysis: firstly, the specific surface area of the recycled aggregate is larger than that of natural aggregate; the contact area increases to enhance the bond strength between the aggregates; secondly, the surface voids of the recycled aggregate is much more than that of natural aggregates, so the grout can fully play its role, and effectively fills into internal porosity of the recycled aggregate, which improves the solidity of the recycled aggregate, making the overall strength of the test piece improved. 
Table 3. The amount of material $(\mathrm{kg} / \mathrm{m} 3)$.

\begin{tabular}{|c|c|c|c|c|c|c|c|c|}
\hline Num. & CA replacement rate (\%) & W/C & Superplasticizer(g) & Pebble & RA & S & W & C \\
\hline 1 & 0 & 0.45 & 20 & 1250.02 & 100 & 673.09 & 148 & 328.89 \\
\hline 2 & 20 & 0.45 & 20 & 1250.02 & 80 & 673.09 & 148 & 328.89 \\
\hline 3 & 25 & 0.45 & 20 & 1250.02 & 75 & 673.09 & 148 & 328.89 \\
\hline 4 & 30 & 0.45 & 20 & 1250.02 & 70 & 673.09 & 148 & 328.89 \\
\hline 5 & 35 & 0.45 & 20 & 1250.02 & 65 & 673.09 & 148 & 328.89 \\
\hline 6 & 40 & 0.45 & 20 & 1250.02 & 60 & 673.09 & 148 & 328.89 \\
\hline 7 & 50 & 0.45 & 20 & 1250.02 & 50 & 673.09 & 148 & 328.89 \\
\hline 8 & 60 & 0.45 & 20 & 1250.02 & 40 & 673.09 & 148 & 328.89 \\
\hline 9 & 70 & 0.45 & 20 & 1250.02 & 30 & 673.09 & 148 & 328.89 \\
\hline 10 & 80 & 0.45 & 20 & 1250.02 & 20 & 673.09 & 148 & 328.89 \\
\hline 11 & 100 & 0.45 & 20 & 1250.02 & 0 & 673.09 & 148 & 328.89 \\
\hline
\end{tabular}

Table 4. Indexes value of concrete.

\begin{tabular}{|c|c|c|c|c|}
\hline $\begin{array}{c}\text { Test block } \\
\text { Numbering }\end{array}$ & $\begin{array}{c}\text { ressure } \\
(\mathbf{k N})\end{array}$ & $\begin{array}{c}\text { Compressive } \\
\text { strength } \\
(\mathbf{M P a})\end{array}$ & $\begin{array}{c}\text { Slump } \\
(\mathbf{~ m m})\end{array}$ & $\begin{array}{c}\text { Mass } \\
(\mathbf{k g})\end{array}$ \\
\hline 1 & 516.033 & 22.933 & 72 & 8.086 \\
\hline 2 & 639.667 & 28.430 & 79 & 7.835 \\
\hline 3 & 788.757 & 35.056 & 70 & 7.920 \\
\hline 4 & 648.000 & 28.8 & 75 & 7.865 \\
\hline 5 & 559.800 & 24.880 & 70 & 7.650 \\
\hline 6 & 521.100 & 23.16 & 73 & 7.486 \\
\hline 7 & 502.425 & 22.33 & 75 & 7.257 \\
\hline 8 & 498.375 & 22.15 & 72 & 7.089 \\
\hline 9 & 481.95 & 21.42 & 74 & 6.881 \\
\hline 10 & 446.625 & 19.85 & 75 & 6.792 \\
\hline 11 & 428.02 & 19.023 & 75 & 6.770 \\
\hline
\end{tabular}

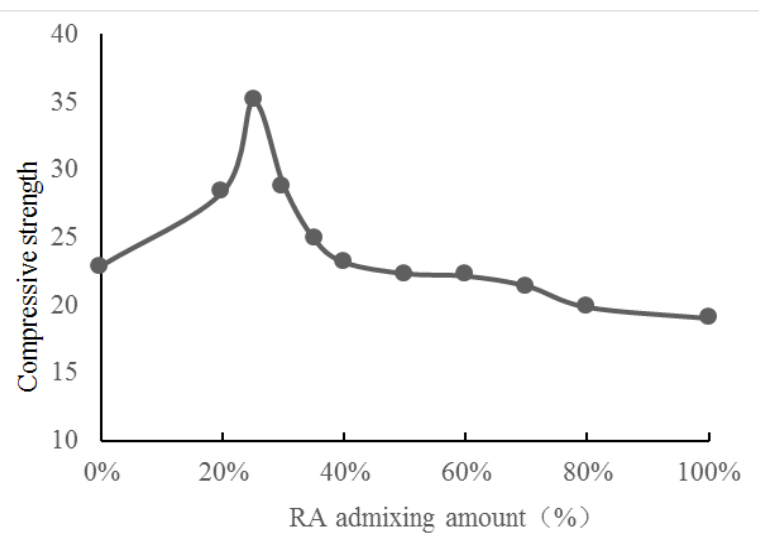

Figure 1. The relations curve between incorporation of recycled aggregate and concrete strength

\section{Conclusions}

The admixing amount of recycled aggregate as a variable was strictly controlled in the testing process; the strength of the test pieces with recycled aggregate first increased and then decreased. Eventually the recycled aggregate range could be drawn upon incorporation of $20 \%$ to $35 \%$; this range could make concrete strength greatly improved. The results showed that the waste clay bricks can not only save resources, but also protect the environment, which will bring great social benefits.

\section{Sources of project funds}

The project fund is the professional project funds of the central university basic scientific research business expenses, the project number of which is 31920150071 , and the innovative entrepreneurial training projects of college students, the project number of which is 201510742066

\section{References}

1. Q. Zhou, Research on Force and Permeability Performance of Mixed Recycled Aggregate Concrete, Xiamen University, a master's degree thesis, (2009)

2. X. Wu, Application of powder and granular construction waste in cement concrete, Zhengzhou University, a master's degree thesis, (2004)

3. Y. Li. Experimental Study on High-Performance Recycled Concrete Produced by Building Waste, Comprehensive utilization of fly ash, (4):17-20 (2013)

4. S. Jia, J. Wang, et al., Construction Waste Recycled Concrete Aggregate Performance Study, Construction Technology, (S1):165-168 (2014)

5. M. Li, Applied Technique Research of Regeneration Concrete by Use of Construction Waste, Municipal Engineering Technology, (S1): 254-260 (2010) 
6. Pebbles, Gravel Used in Building, (GB14685-2001)

7. Ordinary Concrete Mixed Design Procedures, (JGJ 55-2011)

8. S. Song, L. Wang. The Experimental Research on Concrete with Construction Rubbish Recycled
Aggregate, Journal of Wuhan University of Technology (7):56-59 (2009)

9. Building Pebbles, Gravel Modified Version (GB14685-2001)

10. Ordinary Concrete Mixing Performance Test Methods, (GB/T50080-2002) 